\title{
Safety of Epidural Corticosteroid Injections
}

\author{
Ippokratis Pountos $^{1} \cdot$ Michalis Panteli $^{1} \cdot$ Gavin Walters $^{2} \cdot$ Dudley Bush $^{3}$. \\ Peter V. Giannoudis ${ }^{1}$
}

Published online: 29 December 2015

(C) The Author(s) 2015. This article is published with open access at Springerlink.com

\begin{abstract}
Background and Objective Epidural corticosteroid injections (ESIs) have been used for several decades and now represent the most common intervention performed for the management of back pain with a radicular component. However, several reports have presented devastating complications and adverse effects, which fuelled concerns over the risk versus clinical effectiveness. The authors offer a comprehensive review of the available literature and analyse the data derived from studies and case reports.

Methods Studies were identified by searching PubMed MEDLINE, Ovid MEDLINE, EMBASE, Scopus, Google Scholar and the Cochrane Library to retrieve all available relevant articles. Publications from the last 20 years
\end{abstract}

Ippokratis Pountos

pountos@doctors.org.uk

1 Academic Department of Trauma and Orthopaedics, Leeds General Infirmary, Clarendon Wing Level A, Great George Street, Leeds LS1 3EX, UK

2 University of Leeds, Leeds, UK

3 Anaesthetic Department, Leeds Teaching Hospitals, NHS Trust, Leeds, UK
(September 1994 to September 2014) were considered for further analysis. Studies selected were English-language original articles publishing results on complications related to the technique used for cervical and lumbar ESIs. The studies had to specify the approach used for injection. All studies that did not fulfil these eligibility criteria were excluded from further analysis.

Results Overall, the available literature supports the view that serious complications following injections of corticosteroid suspensions into the cervical and lumbar epidural space are uncommon, but if they occur they can be devastating.

Conclusions The true incidence of such complications remains unclear. Direct vascular injury and/or administration of injectates intra-arterially represent a major concern and could account for the vast majority of the adverse events reported. Accurate placement of the needle, use of a non-particulate corticosteroid, live fluoroscopy, digital subtraction angiography, and familiarisation of the operator with contrast patterns on fluoroscopy should minimise these risks. The available literature has several limitations including incomplete documentation, unreported data and inherent bias. Large registries and well-structured observational studies are needed to determine the true incidence of adverse events and address the safety concerns. 


\section{Key Points}

Serious complications including damage to the neural elements, stroke and death have been reported with epidural corticosteroid injections (ESIs) but are mostly anecdotal. Their true incidence is unknown, but such outcomes seem to be rare.

Vascular penetration is possible, relatively more frequent in the cervical segments and potentially hazardous. Intravascular injection can be reduced by use of injected contrast media.

The use of a blunt needle, live fluoroscopy, digital subtraction angiography and the administration of a small test dose initially could help reduce the adverse effects.

Many complications can be avoided by a thorough understanding of the anatomy, accurate placement of the needle and familiarisation of the contrast patterns on fluoroscopy.

More research must be performed regarding the benefits versus risk, techniques and outcome of ESIs.

\section{Introduction}

Epidural corticosteroid injections (ESIs) have been used for decades as a therapeutic modality in the management of spinal pain syndromes attributed to disc pathology and spinal stenosis. Although the exact pathophysiology of these conditions remains obscure, it has been suggested they occur through an ectopic "firing action potentials" mechanism in nerve roots derived from the mechanical compression [1]. This mechanical compression could stimulate a local inflammatory process, which forms the rationale behind the administration of the corticosteroids. This theory is further strengthened by findings suggesting that the lavage of inflammatory mediators may reduce pain and inflammation [2].

Epidural injections can be administered through a transforaminal, interlaminar or caudal route. The interlaminar route is considered to be non-specific and the injectate is free to spread within the posterior epidural space with possible flow anteriorly, cephalad and caudally [3]. This could be influenced by tissue fibrosis, scarring or hypertrophy, which may occur in spinal pathology [4]. Transforaminal ESIs are more specific and selected nerves can be targeted. ESI administered through this route could in theory deposit a larger mass of corticosteroid close to the pain generators at the ventral epidural space allowing a greater degree of drug diffusion, so transforaminal ESI may be more efficacious in alleviating patients' pain [4]. However, several prospective randomised studies have failed to demonstrate a statistically significant difference in terms of pain reduction and functional score improvement between the transforaminal and interlaminar approaches [5, 6]. In a recent systematic literature review of comparative studies involving patients with lumbosacral radicular pain, Chang-Chien et al. [5], suggested that both approaches are equally effective and demonstrated only minor non-significant differences between them. In contrast to the interlaminar and transforaminal routes, caudal epidural injections require relatively higher volumes of corticosteroids but are considered to be easier and safer and are preferred in patients after spinal surgery.

The modality of imaging may influence the efficacy of ESI. Currently, fluoroscopy, ultrasound and computed tomography (CT) imaging have been used and their utilisation continues to increase. The choice amongst them partly lies in personal preference but also on the availability and prior training on the device. Limited evidence currently exists in terms of the effectiveness and safety differences between these techniques. For instance, a recent literature review by Bui and Bogduk [7] concluded that CT-guided lumbar transforaminal injection of corticosteroids is neither more effective nor safer than the fluoroscopy-guided injections but that CT is associated with significantly higher radiation doses than conventional fluoroscopy. Ultrasound has gained popularity and maybe a safe alternative to the other radiological imaging modalities [8].

\section{Risk Versus Efficacy of Epidural Corticosteroid Injections (ESIs)}

Several authors have questioned the overall efficacy of ESIs for the management of radicular pain [9-12]. In a systematic review of the available literature in 2009 by Chou et al. [9], ESIs were moderately effective for short-term symptom relief in patients with low back pain but conferred no longterm benefit. In a similar manuscript, Pinto et al. [11] concluded that epidural corticosteroid injections offer only short-term relief of leg pain and disability for patients with sciatica. The authors questioned the clinical justification of this procedure when comparing the benefits with the risks. Furthermore, in a systematic review including data from the Cochrane Central Register of Controlled Trials, Staal et al. [12] concluded that there is insufficient evidence to support the use of injection therapy in subacute and chronic low back pain. These conclusions have been challenged by several other trials and systematic reviews [13-18]. In patients with lumbar radicular pain caused by contained disc herniations, MacVicar et al. [16] suggested that lumbar transforaminal 
injection of corticosteroids is effective in reducing pain, restoring function, reducing the need for other healthcare modalities and avoiding surgery [16]. In line with these deductions, Quraishi [18] concluded that in patients with lumbar radiculopathy, ESIs result in an improvement in pain but not disability. Friedly et al. [10] suggested that epidural injection of glucocorticoids plus lidocaine offered minimal or no short-term benefit as compared with epidural injection of lidocaine in the treatment of lumbar spinal stenosis alone. ESIs were found to have significant effect in relieving chronic intractable pain of cervical origin, providing longterm relief [14]. Some meta-analyses suggested that there is good evidence for the effectiveness of cervical interlaminar epidural injections in managing radiculitis secondary to disc herniation and fair evidence in managing axial or discogenic pain, pain of central spinal stenosis and pain of post-surgery syndrome $[15,17]$. The same authors concluded that the evidence is poor for cervical transforaminal epidural injections. It should be mentioned, however, that several of these studies have been criticised for flaws and deficiencies, adding further overall confusion.

In addition to the controversy surrounding the efficacy of ESIs, some authors have raised concerns regarding potential adverse events. On 23 April 2014 the US Food and Drug Administration (FDA) issued a warning to the medical community covering the potential risks of these injections [19]. The warning states that "injection of corticosteroids into the epidural space of the spine may result in rare but serious adverse events, including loss of vision, stroke, paralysis, and death".

This systematic review aims to scrutinise the available literature, present the available data and documentation from several authors, and analyse the risks involved with the ESIs in the cervical and lumbar spine.

\section{Methods}

This review was carried out in accordance to the PRISMA guidelines [20]. Data were documented according to a standardised protocol, where objectives and inclusion criteria were specified in detail.

Publications from the last 20 years (September 1994 to September 2014) were considered for further analysis. Studies selected were original articles, in the English language, publishing results on complications related to the technique used for the ESIs. Only cervical and lumbar ESIs were included and the studies had to specify the approach used for injection. All studies that did not fulfil these eligibility criteria were excluded from further analysis.

Studies were identified by searching the following resources/databases to retrieve all available relevant articles: PubMed MEDLINE, Ovid MEDLINE, EMBASE,
Scopus, Google Scholar and the Cochrane Library. The terms used for the search included 'epidural', 'injection', 'corticosteroid' and 'steroid' both isolated or in combination with specific words including 'transforaminal', 'interlaminar', 'adverse events', 'complication' and 'side effect'. The identified articles and their bibliographies including any relevant reviews were manually searched for additional potential eligible studies.

Two of the authors (Ippokratis Pountos and Gavin Walters) of this systematic review performed 208 the assessment, in an independent, unblinded and standardised manner. Most citations were excluded on the basis of information provided by their respective title or abstract. In any other case, the complete manuscript was obtained and scrutinised by two reviewers.

\section{Results}

Of 3255 papers initially identified, 162 met the inclusion criteria (Fig. 1). This included 58 studies, of which 38 recorded complications while the remaining 20 state that 217 no complications were encountered [21-78]. 101 case reports were also found [79-179].

\subsection{Interlaminar Cervical ESIs}

The review of the available literature identified 11 manuscripts presenting complications following interlaminar cervical ESIs (Table 1) [21, 22, 24, 26, 28-34]. One

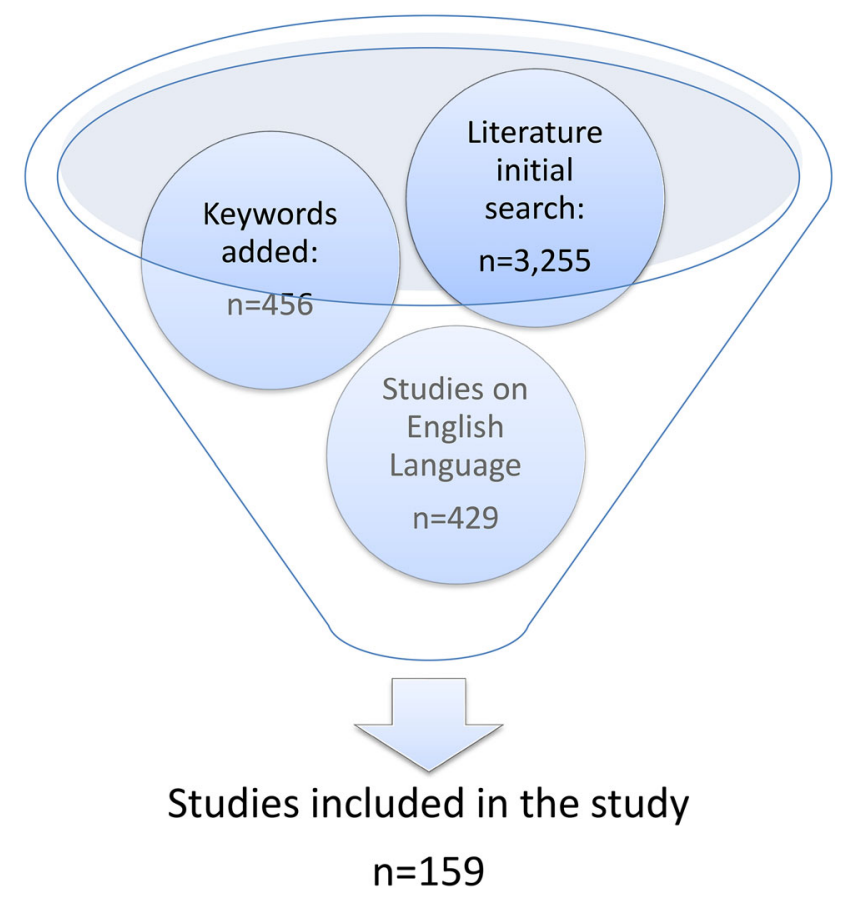

Fig. 1 Flowchart of study selection 
Table 1 Complications reported with interlaminar cervical epidural corticosteroid injections

\begin{tabular}{|c|c|c|c|c|c|}
\hline Study, year & Design & Pts & Medications & Imaging & Complications \\
\hline $\begin{array}{l}\text { Botwin et al., } 2003 \\
\text { [22] }\end{array}$ & $\begin{array}{l}\text { Retrospective } \\
\text { cohort study }\end{array}$ & $\begin{array}{l}157 \text { pts, } 345 \text { injections, } \\
\text { C6-7 or C7-T1 }\end{array}$ & $\begin{array}{l}\text { Triamcinolone acetonide } \\
80 \mathrm{mg}\end{array}$ & FL & $\begin{array}{l}\text { Overall } 16.8 \% \text { : } \\
23 \text { Increased neck pain }(6.7 \%) \\
16 \text { Non-positional headaches } \\
(4.6 \%) \\
6 \text { Insomnia }(1.7 \%) \\
6 \text { Vasovagal reactions }(1.7 \%) \\
5 \text { Facial flushing }(1.5 \%) \\
1 \text { Pyrexia }(0.3 \%) \\
1 \text { Dural puncture }(0.3 \%)\end{array}$ \\
\hline $\begin{array}{l}\text { Derby et al., } 2003 \\
\text { [24] }\end{array}$ & $\begin{array}{l}\text { Retrospective } \\
\text { survey }\end{array}$ & 4389 Injections & NA & NA & $\begin{array}{l}3 \text { Dural punctures }(0.07 \%) \\
17 \text { Vagal symptoms }(0.4 \%) \\
3 \text { Paraesthesia and numbness } \\
(0.07 \%)\end{array}$ \\
\hline $\begin{array}{l}\text { Goel and Pollan, } \\
2006[26]\end{array}$ & $\begin{array}{l}\text { Prospective } \\
\text { cohort }\end{array}$ & 29 pts, 65 injections & NA & FL & $\begin{array}{l}16.9 \% \text { headaches } \\
21.5 \% \text { insomnia, flushing of the } \\
\text { face, temperature } \\
6.2 \% \text { of increased pain }\end{array}$ \\
\hline $\begin{array}{l}\text { Kwon et al., } 2007 \\
\text { [29] }\end{array}$ & $\begin{array}{l}\text { Retrospective } \\
\text { cohort study }\end{array}$ & $76 \mathrm{pts}, 76$ injections & $\begin{array}{l}\text { Triamcinolone acetonide } \\
\quad 40 \mathrm{mg}\end{array}$ & FL & 2 Dural punctures $(2.6 \%)$ \\
\hline $\begin{array}{l}\text { Kranz et al., } 2011 \\
\text { [28] }\end{array}$ & $\begin{array}{l}\text { Retrospective } \\
\text { cohort study }\end{array}$ & 50 pts, 53 injections & Betamethasone & $\mathrm{CT}$ & 1 Intra-thecal injection \\
\hline $\begin{array}{l}\text { Manchikanti et al., } \\
2012 \text { [34] }\end{array}$ & $\begin{array}{l}\text { Prospective } \\
\text { cohort study }\end{array}$ & 2376 Injections & NA & FL & $\begin{array}{l}100 \text { Intravascular placement of } \\
\text { needle }(4.2 \%) \\
24 \text { Dural puncture }(1 \%) \\
6 \text { Transient nerve root irritation } \\
(0.25 \%) \\
5 \text { Transient spinal cord irritation } \\
(0.21 \%) \\
16 \text { Profuse bleeding }(0.7 \%) \\
1 \text { Vasovagal }(0.04 \%) \\
2 \text { Facial flushing }(0.08 \%)\end{array}$ \\
\hline $\begin{array}{l}\text { Lee et al., } 2012 \\
\text { [31] }\end{array}$ & $\begin{array}{l}\text { Prospective } \\
\text { cohort study }\end{array}$ & $\sim 127$ Injections & $\begin{array}{l}\text { Dexamethasone sodium } \\
\text { phosphate } 10 \mathrm{mg}\end{array}$ & FL & $\begin{array}{l}1 \text { Vasovagal and syncope } \\
(0.8 \%) \\
1 \text { Dural puncture }(0.8 \%)\end{array}$ \\
\hline $\begin{array}{l}\text { Beyaz and Eman, } \\
2013 \text { [21] }\end{array}$ & $\begin{array}{l}\text { Retrospective } \\
\text { cohort study }\end{array}$ & $65 \mathrm{pts}$ & NA & FL & $\begin{array}{l}1 \text { Vasovagal }(1.54 \%) \\
1 \text { Transient increase of pain } \\
(1.54 \%)\end{array}$ \\
\hline $\begin{array}{l}\text { Manchikanti et al., } \\
2013 \text { [33] }\end{array}$ & RCT & 120 pts, 654 injections & $\begin{array}{l}\text { Betamethasone } 6 \mathrm{mg} \\
(n=60)\end{array}$ & FL & $\begin{array}{l}2 \text { Subarachnoid punctures } \\
(0.3 \%) \\
4 \text { Intravascular penetrations } \\
(0.6 \%) \\
5 \text { Nerve root irritations }(0.76 \%) \\
1 \text { Pain lasting } 1 \text { week }(0.15 \%)\end{array}$ \\
\hline $\begin{array}{l}\text { Lee et al., } 2014 \\
\text { [30] }\end{array}$ & $\begin{array}{l}\text { Retrospective } \\
\text { cohort study }\end{array}$ & 143 pts & $\begin{array}{l}\text { Triamcinolone acetonide } \\
\quad 40 \mathrm{mg}\end{array}$ & & $\begin{array}{l}1 \text { Itching sensations } \\
1 \text { Facial flushing } \\
1 \text { Dry mouth } \\
1 \text { Erectile dysfunction }\end{array}$ \\
\hline
\end{tabular}


Table 1 continued

\begin{tabular}{|c|c|c|c|c|c|}
\hline Study, year & Design & Pts & Medications & Imaging & Complications \\
\hline \multirow[t]{4}{*}{$\begin{array}{l}\text { Manchikanti et al., } \\
2014 \text { [32] }\end{array}$} & \multirow[t]{4}{*}{$\mathrm{RCT}$} & \multirow[t]{4}{*}{120 pts, 688 injections } & \multirow[t]{4}{*}{$\begin{array}{l}\text { Betamethasone } 6 \mathrm{mg} \\
\quad(n=60)\end{array}$} & \multirow[t]{4}{*}{ FL } & $\begin{array}{l}\text { 6 Subarachnoid punctures } \\
(0.3 \%)\end{array}$ \\
\hline & & & & & $\begin{array}{l}10 \text { Intravascular penetrations } \\
(0.6 \%)\end{array}$ \\
\hline & & & & & 3 Nerve root irritations $(0.76 \%)$ \\
\hline & & & & & 1 Pain lasting 1 week $(0.15 \%)$ \\
\hline
\end{tabular}

$C T$ computed tomography, $F L$ fluoroscopy, $N A$ not available, pts patients, $R C T$ randomised controlled trial

manuscript that reports no complications has also been identified but only includes 14 interlaminar cervical ESIs [23].

Based on the available studies, the incidence of dural puncture ranged between 0.07 and $2.6 \%$. Vasovagal reactions ranged between 0.04 and $1.7 \%$. In a prospective study including 2376 injections, Manchikanti et al. [34] reported 100 cases where intravascular placement of the needle occurred [34]. However, complications that could potentially be correlated with inadvertent intravascular injection of corticosteroids were low and included 11 cases of transient nerve root or spinal cord irritation, one vasovagal event and two cases of facial flushing. In a retrospective analysis of the results of 345 C6-7 or C7-T1 injections, Botwin et al. [22] reported an overall incidence of complications of $16.8 \%$. A large proportion of these adverse events were related to an increase of neck pain, headache, insomnia and vasovagal reactions.

\subsection{Transforaminal Cervical ESIs}

There are limited studies analysing the complications from this approach. Furman et al. [25] presented 504 cervical (C3-C8) transforaminal ESIs performed on 337 patients [25]. They reported identification of 98 intravascular injections that did not result in any adverse effects. Similarly, other authors have reported no complications [27, 31, 37-39]. In a retrospective review of 1579 injections, Derby et al. [24] reported two cases of aggravated radicular pain, two cases of prolonged paraesthesias and the development of skin rash in one patient. In another study including 43 ESIs with prednisolone, $19 \%$ of patients experienced minor neurovegetative manifestations [43]. Scanlon et al. [41] conducted an anonymous survey asking the US physician members of the American Pain Society about their experience with regards to serious complications following cervical transforaminal epidural corticosteroid injections (TESIs) [41]. From the 287 replies, 78 complications were reported, among which there were 30 brain or spinal cord infarcts and 24 neurologic complications including death of unsuspected aetiology $(n=5)$, high spinal anaesthesia $(n=3)$, transient ischaemic attacks $(n=3)$, and spinal cord or brainstem oedema $(n=3)$. Overall, the survey revealed 13 cases with a fatal outcome [41].

\subsection{Interlaminar Lumbar ESIs}

The literature search found 11 studies that present adverse effects following interlaminar lumbar ESIs (Table 2) [34$36,40,42,44,45,47-52]$. In addition, four studies that involve more than 250 patients have reported no adverse events following interlaminar lumbar epidural ESIs [46, $54,55,60]$. In a prospective cohort study including 1450 injections, Manchikanti et al. [34] reported an incidence of $0.8 \%$ for dural puncture and profuse bleeding following the injection [34]. A prospective, randomised blinded study including 106 patients has reported a rather high number of minor adverse effects [35]. In particular, $26 \%$ of the patients experienced discomfort and pain at the injection site, $18 \%$ had non-positional headache and $10 \%$ suffered from nausea after the injection. In an analysis of 6631 interlaminar lumbar ESIs, Huang et al. [48] found 42 cases of inadvertent lumbar facet joint injection [48]. In 31 cases the physician recognised the lumbar facet joint injection. A similar study design reported by Candido et al. [46] reported the incidence of intradiscal injection to be one in 4723 [46].

\subsection{Transforaminal Lumbar ESIs}

Fourteen studies were identified that presented adverse effects following transforaminal ESIs (Table 3) [34, 50, 53, 56-59, 61, 63, 65-69]. In contrast, no adverse events were presented by a number of other authors [25, 62, 7078]. McGrath et al. [59] retrospectively reviewed the charts of patients receiving ESIs over a 7-year period [59]. Of the 3964 injections included, only minor complications were reported in 84 injections. The most common complication reported was increased pain, which was encountered in half of the patients. Two prospective studies analysing a large number of transforaminal lumbar ESIs reported an incidence of intravascular penetration of between 7.4 and $7.9 \%$ [34, 
Table 2 Complications reported with interlaminar lumbar epidural corticosteroid injections

\begin{tabular}{|c|c|c|c|c|c|}
\hline Study, year & Design & Pts & Medications & Imaging & Complications \\
\hline $\begin{array}{l}\text { Carette et al., } \\
1997 \text { [36] }\end{array}$ & $\begin{array}{l}\text { Prospective } \\
\text { randomised } \\
\text { blinded study }\end{array}$ & $\begin{array}{r}78 \text { pts, } 162 \\
\text { injections }\end{array}$ & Methylprednisolone $80 \mathrm{mg}$ & BL & $\begin{array}{l}1 \text { Dural puncture }(0.6 \%) \\
27 \text { Transient headache }\end{array}$ \\
\hline $\begin{array}{l}\text { Kraemer et al., } \\
1997 \text { [51] }\end{array}$ & RCT & $\begin{array}{l}87 \text { pts, } 87 \\
\text { injections }\end{array}$ & Triamcinolone $10 \mathrm{mg}$ & $\mathrm{CT}$ & $1.9-3.6 \%$ headache \\
\hline $\begin{array}{l}\text { Valat et al., } 2003 \\
\text { [42] }\end{array}$ & $\mathrm{RCT}$ & $\begin{array}{r}39 \mathrm{pts}, 117 \\
\text { injections }\end{array}$ & Prednisolone acetate $50 \mathrm{mg}$ & BL & 2 Headache \\
\hline $\begin{array}{l}\text { Arden et al., } \\
2005 \text { [44] }\end{array}$ & RCT & $\begin{array}{l}115 \mathrm{pts}, 3 \\
\text { injections } \\
\text { each }\end{array}$ & Triamcinolone acetonide $80 \mathrm{mg}$ & BL & $\begin{array}{l}4 \text { Non-specific headache } \\
2 \text { Postdural puncture } \\
\text { headache, nausea } \\
5 \text { Other }\end{array}$ \\
\hline $\begin{array}{l}\text { Kim et al., } 2010 \\
\text { [49] }\end{array}$ & $\begin{array}{l}\text { Retrospective } \\
\text { cohort study }\end{array}$ & $\begin{array}{l}150 \mathrm{pts}, 150 \\
\text { injections }\end{array}$ & Dexamethasone $16 \mathrm{mg}$ & FL & 42 Facial flushing ( $28 \%$ ) \\
\hline $\begin{array}{l}\text { Kim et al., } 2011 \\
\text { [50] }\end{array}$ & $\begin{array}{l}\text { Prospective } \\
\text { randomised study }\end{array}$ & $\begin{array}{r}60 \mathrm{pts}, 120 \\
\text { injections }\end{array}$ & $\begin{array}{l}\text { Dexamethasone phosphate } 15 \mathrm{mg} \text { or } \\
\text { methylprednisolone acetate } 80 \mathrm{mg}\end{array}$ & FL & 1 Intrathecal injection \\
\hline $\begin{array}{l}\text { Manchikanti } \\
\text { et al., } 2012 \text { [34, } \\
\text { 40] }\end{array}$ & $\begin{array}{l}\text { Prospective } \\
\text { randomised } \\
\text { blinded study }\end{array}$ & $\begin{array}{l}120 \mathrm{pts}, 213 \\
\text { injections }\end{array}$ & Betamethasone $1 \mathrm{~mL}(n=60)$ & FL & $\begin{array}{l}3 \text { Subarachnoid punctures } \\
(1.4 \%)\end{array}$ \\
\hline $\begin{array}{l}\text { Manchikanti } \\
\text { et al., } 2012 \text { [34] }\end{array}$ & $\begin{array}{l}\text { Prospective cohort } \\
\text { study }\end{array}$ & $\begin{array}{l}1450 \\
\text { Injections }\end{array}$ & NA & FL & $\begin{array}{l}7 \text { Intravascular placement of } \\
\text { needle }(0.5 \%) \\
4 \text { Transient nerve root } \\
\text { irritation }(0.28 \%) \\
11 \text { Dural punctures }(0.8 \%) \\
11 \text { Profuse bleeding }(0.8 \%) \\
4 \text { Local haematoma } \\
(0.28 \%) \\
1 \text { Headache }(0.07 \%) \\
2 \text { Facial flushing }(0.13 \%)\end{array}$ \\
\hline $\begin{array}{l}\text { Bartynski et al., } \\
2013[45]\end{array}$ & $\begin{array}{l}\text { Retrospective } \\
\text { cohort study }\end{array}$ & $\begin{array}{l}276 \text { pts, } 392 \\
\text { injection }\end{array}$ & Methylprednisolone acetate $80 \mathrm{mg}$ & FL & $\begin{array}{l}1 \text { Dural puncture } \\
1 \text { Transient paraparesis }\end{array}$ \\
\hline $\begin{array}{l}\text { Candido el al. } \\
2013[35]\end{array}$ & $\begin{array}{l}\text { Prospective } \\
\text { randomised } \\
\text { blinded study }\end{array}$ & $\begin{array}{l}106 \text { pts, L3- } \\
\quad \text { S1 }\end{array}$ & Methylprednisolone acetate $120 \mathrm{mg}$ & FL & $\begin{array}{l}26 \% \text { discomfort and pain at } \\
\text { the injection site } \\
18 \% \text { non-positional } \\
\text { headache } \\
10 \% \text { nausea }\end{array}$ \\
\hline $\begin{array}{l}\text { Evansa et al., } \\
2015 \text { [47] }\end{array}$ & $\begin{array}{l}\text { Prospective } \\
\text { randomised study }\end{array}$ & $\begin{array}{l}120 \mathrm{pts}, 120 \\
\text { injections }\end{array}$ & Methylprednisolone acetate $80 \mathrm{mg}$ & $\begin{array}{l}\text { FL }(n=56), \\
\quad \text { US } \\
\quad(n=56)\end{array}$ & $\begin{array}{l}15 \text { Dizziness or pain at } \\
\text { injection site or facial } \\
\text { flushing } \\
1 \text { Intrathecal injection }\end{array}$ \\
\hline
\end{tabular}

$B L$ blind, $C T$ computed tomography, $F L$ fluoroscopy, $N A$ not available, pts patients, $R C T$ randomised controlled trial, $U S$ ultrasound

57]. The main difference was an $8.7 \%$ rate of vasovagal episodes reported by Karaman et al. [57]. A similar rate was reported by Ploumis et al. [61], although only 20 patients were included in that study. Hong et al. [56] identified six intradiscal injections among 249 transforaminal ESIs, which represents an incidence of $2.4 \%$ [56]. A lower incidence of one in 402 injections was reported by Candido et al. [46], although this was tenfold higher than after interlaminar ESI [46].

\subsection{Adverse Event Case Reports According to the Approach Used}

A large number of case reports presenting rare adverse events following ESIs exist (Fig. 2) [79-179]. The available literature has described deaths following ESIs [89, 93, 97]. Reviewing the available case reports, the most common and devastating complication was infarction of the spinal cord, cerebellum, brain and brainstem [97, 141]. 
Table 3 Complications reported with transforaminal lumbar epidural corticosteroid injections

\begin{tabular}{|c|c|c|c|c|c|}
\hline Study, year & Design & Pts & Medications & Imaging & Complications \\
\hline $\begin{array}{l}\text { Botwin et al., } \\
2000[53]\end{array}$ & $\begin{array}{l}\text { Retrospective } \\
\text { cohort study }\end{array}$ & $\begin{array}{c}207 \text { pts, } 322 \\
\text { injections }\end{array}$ & $\begin{array}{l}\text { Either betamethasone } \\
9-12 \mathrm{mg} \text { or } \\
\text { methylprednisolone } 80 \mathrm{mg}\end{array}$ & FL & $\begin{array}{l}10 \text { Non-positional headaches }(3.1 \%) \\
8 \text { Increased back pain }(2.4 \%) \\
2 \text { Increased leg pain }(0.6 \%) \\
4 \text { Facial flushing }(1.2 \%) \\
1 \text { Vasovagal reaction }(0.3 \%) \\
1 \text { Increased blood sugar }(258 \mathrm{mg} / \mathrm{dL}) \text { in an } \\
\text { insulin-dependent patient with diabetes } \\
\text { mellitus }(0.3 \%) \\
1 \text { Intraoperative hypertension }(0.3 \%)\end{array}$ \\
\hline $\begin{array}{l}\text { Ahadian et al., } \\
2011[62]\end{array}$ & $\begin{array}{l}\text { Prospective } \\
\text { randomised } \\
\text { study }\end{array}$ & $\begin{array}{l}98 \text { pts, } 98 \\
\text { injections }\end{array}$ & Dexamethasone 4,8 or $12 \mathrm{mg}$ & FL & $\begin{array}{l}1 \text { Pain at injection site } \\
5 \text { Vascular uptake } \\
6 \text { Paraesthesia during procedure }\end{array}$ \\
\hline $\begin{array}{l}\text { Karaman et al., } \\
2011[57]\end{array}$ & $\begin{array}{l}\text { Prospective } \\
\text { cohort study }\end{array}$ & $\begin{array}{l}562 \text { pts, } \\
1305 \\
\text { injections }\end{array}$ & Triamcinolone acetonide & FL & $\begin{array}{l}97 \text { Vascular penetration }(7.4 \%) \\
8.7 \% \text { vasovagal episodes } \\
5 \text { Transient erectile dysfunction }(0.9 \%) \\
5 \text { Facial flushing }(0.9 \%)\end{array}$ \\
\hline $\begin{array}{l}\text { McGrath et al., } \\
2011 \text { [59] }\end{array}$ & $\begin{array}{l}\text { Retrospective } \\
\text { cohort study }\end{array}$ & $\begin{array}{l}1667 \text { pts, } \\
3964 \\
\text { injections }\end{array}$ & NA & FL & $\begin{array}{l}42 \text { Increased pain } \\
6 \text { Numbness } \\
9 \text { Pain at injection site }\end{array}$ \\
\hline $\begin{array}{l}\text { Manchikanti } \\
\text { et al., } 2012 \text { [34] }\end{array}$ & $\begin{array}{l}\text { Prospective } \\
\text { cohort study }\end{array}$ & $\begin{array}{l}1310 \\
\text { Injections }\end{array}$ & NA & FL & $\begin{array}{l}104 \text { Intravascular placement of needle }(7.9 \%) \\
16 \text { Transient nerve root irritation }(4.6 \%) \\
8 \text { Profuse bleeding }(1 \%) \\
1 \text { Vasovagal }(0.08 \%) \\
2 \text { Facial flushing }(0.15 \%)\end{array}$ \\
\hline $\begin{array}{l}\text { Cansever et al., } \\
2012 \text { [63] }\end{array}$ & $\begin{array}{l}\text { Prospective } \\
\text { cohort study }\end{array}$ & 153 pts & Methylprednisolone $40 \mathrm{mg}$ & FL & 2 Discitis \\
\hline $\begin{array}{l}\text { Wewalka et al., } \\
2012 \text { [69] }\end{array}$ & Cohort study & $\begin{array}{l}37 \text { pts, } 65 \\
\text { injections }\end{array}$ & Triamcinolone $40 \mathrm{mg}$ & $\mathrm{CT}$ & $\begin{array}{l}3 \text { Transient weakness } \\
14 \text { Increased low back pain } \\
2 \text { Low blood pressure post-injection }\end{array}$ \\
\hline $\begin{array}{l}\text { Koh et al., } 2013 \\
\text { [65] }\end{array}$ & $\mathrm{RCT}$ & $53 \mathrm{pts}$ & Triamcinolone $20 \mathrm{mg}$ & FL & 1 Burning at injection site (1.9\%) \\
\hline $\begin{array}{l}\text { Manson et al., } \\
2013 \text { [58] }\end{array}$ & $\begin{array}{l}\text { Retrospective } \\
\text { cohort study }\end{array}$ & $\begin{array}{l}91 \text { pts, } 106 \\
\text { injections }\end{array}$ & Triamcinalone $40 \mathrm{mg}$ & FL & 2 Vasovagal episodes \\
\hline $\begin{array}{l}\text { Hong et al., } 2014 \\
\text { [56] }\end{array}$ & $\begin{array}{l}\text { Prospective } \\
\text { cohort study }\end{array}$ & $\begin{array}{c}239 \text { pts, } 249 \\
\text { injections }\end{array}$ & $\begin{array}{l}\text { Dexamethasone } 5 \mathrm{mg} \text { and } \\
\text { mepivacaine } 3 \mathrm{~mL}\end{array}$ & FL & 6 Intradiscal injection \\
\hline $\begin{array}{l}\text { Manchikanti } \\
\text { et al., } 2014 \text { [67] }\end{array}$ & RCT & $\begin{array}{l}120 \text { pts, } 601 \\
\text { injections }\end{array}$ & Betamethasone $3 \mathrm{mg}$ & FL & $\begin{array}{l}28 \text { Intravascular infiltrations }(4.6 \%) \\
9 \text { Nerve root irritations }(1.5 \%)\end{array}$ \\
\hline $\begin{array}{l}\text { Kraiwattanapong } \\
\text { et al., } 2014 \text { [66] }\end{array}$ & $\begin{array}{l}\text { Prospective } \\
\text { cohort study }\end{array}$ & $\begin{array}{l}38 \text { pts, } 72 \\
\text { injections }\end{array}$ & Methylprednisolone $80 \mathrm{mg}$ & FL & 3 Worsening of leg pain \\
\hline $\begin{array}{l}\text { Ploumis et al., } \\
2014[61]\end{array}$ & $\begin{array}{l}\text { Prospective } \\
\text { cohort study }\end{array}$ & $\begin{array}{l}20 \text { pts, L4- } \\
\quad \text { S1 }\end{array}$ & Betamethasone $9 \mathrm{mg}$ & FL & 2 Vasovagal episodes $(10 \%)$ \\
\hline $\begin{array}{l}\text { Tauheed et al., } \\
2014 \text { [68] }\end{array}$ & $\mathrm{RCT}$ & $60 \mathrm{pts}$ & Methylprednisolone $60 \mathrm{mg}$ & FL & 3 Transient paraesthesia of nerve distribution \\
\hline
\end{tabular}

$C T$ computed tomography, $F L$ fluoroscopy, $N A$ not available, pts patients, $R C T$ randomised controlled trial

Infarctions could occur due to damage to the blood vessels, or either to vasospasm or an emboli from particulate matter associated with the corticosteroid injection. Damage to the blood vessels could result in haematomas, and subdural and epidural haematomas have been reported [124, 135, 144,
146, 155, 162, 164]. Permanent paralysis can occur following such haematomas [145]. Direct damage to the spinal cord by trauma or direct injection of ESI medications into the cervical spinal cord has been also documented [140, 148, 160, 173]. Such a complication can 


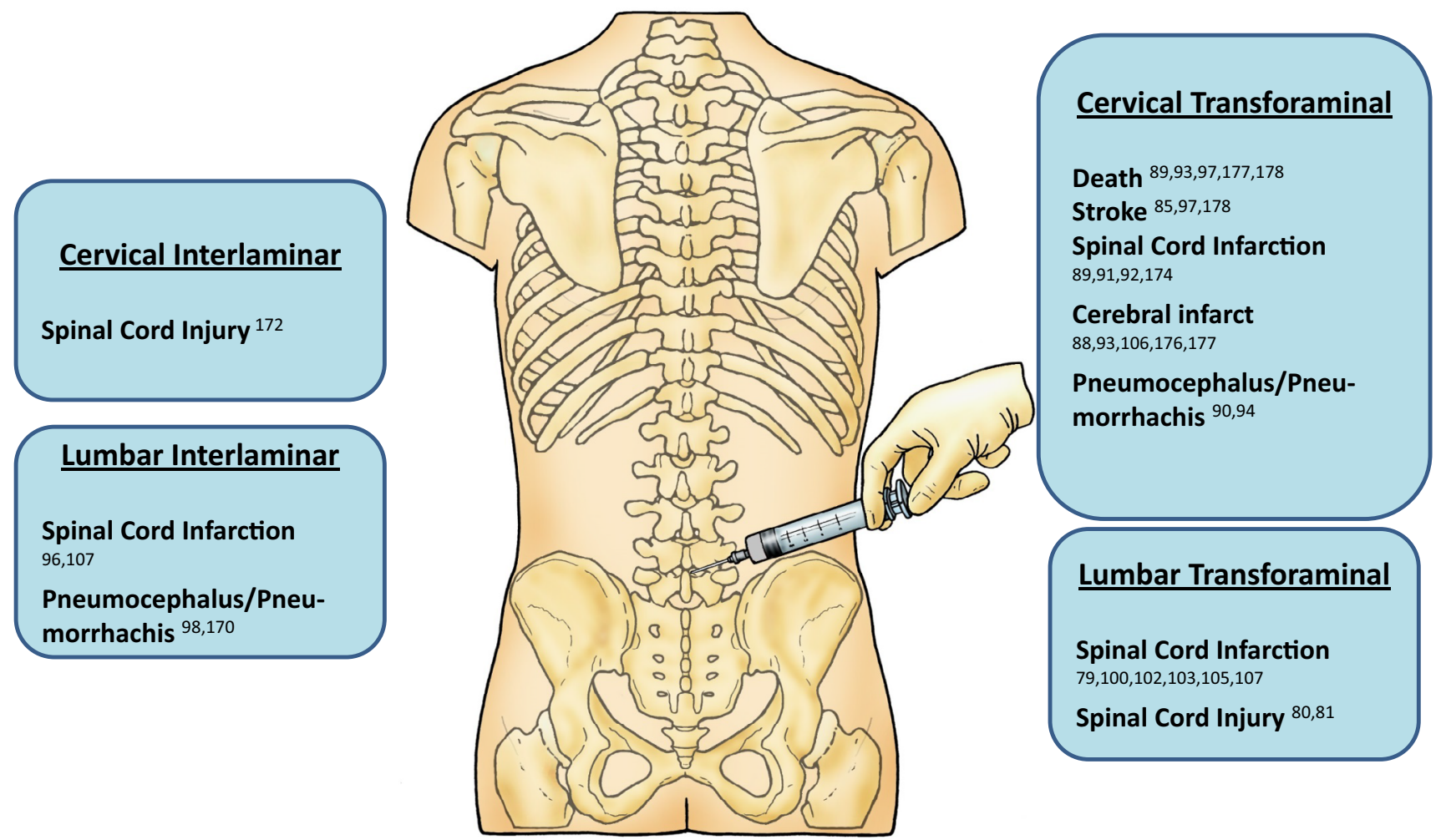

Fig. 2 Reported major complications and approach used

occur with an absence of pain being reported by the patient when the spinal cord structures were punctured [156]. Subdural and intrathecal spread or diffusion of the injected mixture of corticosteroids, anaesthetic and contrast dye could result in cauda equina and conus medularis syndromes, arachnoiditis, meningitis and temporary respiratory depression [139, 148, 153, 171]. Intracranial subdural haematoma after accidental dural puncture has also been presented [142]. Furthermore, cases of pneumocephalus, pneumorrhachis and cerebrospinal fluid (CSF) leak can occur $[90,94,95,147,151,153,170]$.

Infections and abscesses have been also reported following ESI [108-114, 117-127, 130, 132, 133, 164]. With the exception of a fungal infection outbreak in the USA in 2012, infection rates are considered rare [109]. Infection rates vary following an epidural injection, but, on average, are reported to be one in 60,000-100,000 epidural injections [112]. The documented outbreak in 2012 was possibly caused by a contaminated glucocorticoid product used for epidural and paraspinal injection [108, 109]. In single case reports, cases of meningitis, vertebral osteomyelitis, and spinal and paraspinal abscesses have been reported that are caused by microorganisms including Aspergillus spp., Staphylococcus aureus and methicillin-resistant S. aureus $[111,113,126]$. Patients' skin flora has been proposed to be the most common source of infection [125].
Blindness after ESI has been reported multiple times [82-84, 86, 87, 154, 167]. It has been hypothesised that this complication is caused by an abrupt rise in the CSF pressure caused by the volume of the injected pharmaceutical agents. In the cervical spine, this complication can be the result of the administration of radio contrast agents administered in the intracranial vasculature [84]. The patient's vision returned to normal within 1 year of followup in some studies [82, 83], but permanent visual impairment in patients' vision was reported by some authors [84, 86, 87, 167].

Vaginal bleeding has been reported as a potential complication of ESI [99, 101]. Suh-Burgmann et al. [116] have retrospectively reviewed 8166 ESI procedures and reported an incidence of $2.5 \%(n=201 ; 197$ patients) for abnormal vaginal bleeding [116]. Of these women, $70 \%$ were premenopausal and $30 \%$ were postmenopausal. Suppression of the hypothalamic-pituitary-ovarian axis causing anovulatory cycles has been hypothesised to be the mechanism for this adverse effect [115].

Case reports have also presented other complications including iatrogenic Cushing's syndrome [131, 166], persistent hiccups [128, 152], convulsions [129], reversible posterior leukoencephalopathy syndrome [82], epidural granuloma formation [150], subdural block [157], BrownSéquard syndrome [159], herpes zoster outbreak [165], 
steroid myopathy [166] and corticosteroid-induced psychosis [137] following ESI. Spinal epidural lipomatosis is a rare condition of adipose tissue hypertrophy in the epidural space and has been reported to occur after ESI [138, 143, 161]. In addition, cardiopulmonary arrest following ESI and anaphylaxis and other adverse events due to the epidural corticosteroid compounds can occur [134, 136, 149, 169, 175]. Complex regional pain syndrome and development of neuropathic pain following ESI have also occurred $[158,163]$.

\section{Discussion}

ESIs have been used for more than 60 years since Lievre et al. [180] reported the use of epidural hydrocortisone in a series of 20 patients. Over the years, their use has expanded significantly. In Medicare beneficiaries in the USA, the number of epidural injections has increased by $106.3 \%$ in the decade between 1997 and 2006 [181]. Currently, ESIs are the most common intervention performed for the management of chronic low back pain in the USA [182]. Nevertheless, their clinical need and effectiveness has been questioned by several studies [10]. Indications for ESI are not robust and the outcome could not be correlated with the extent of the underlying pathology, e.g. the degree of lumbar spinal stenosis, but could be determined by factors such as age, sex and the preceding opioid use [183-185].

Collectively, this systematic review contains data from more than 100,000 ESIs reported in prospective or retrospective studies. The reported complications were minor in the vast majority. Major events have been reported anecdotally and it is impossible to comment on their true incidence based on the available results in the literature. Overall, the potential causes of adverse events could be categorised into three distinct categories: (1) direct damage to the blood vessels or adjacent anatomical structures during the procedure; (2) intravascular administration of the injectate; and (3) a local or systemic reaction including bacterial contamination.

Direct damage to the blood vessels or adjacent structure is an inherent risk for any injection, including ESIs. Direct damage to the spinal cord by the needle and the injection of corticosteroids into the cervical spinal cord has been also documented in a very limited number of case reports. Clinically significant haematomas derived from piercing or damage to the blood vessels can occur and the reported incidence for all epidurals is less than one in 150,000. This complication is increased in patients with coagulopathy and patients on anticoagulant medications [186-188]. Inadvertent dural punctures can occur after ESIs and CSF flashback is pathognomonic of this complication. Other complications, including intracranial subdural haematoma after accidental dural puncture and cases of pneumocephalus, pneumorrhachis and CSF leak, have been presented in case reports [90, 94, 95, 98].

Intravascular injection of the corticosteroids, carrier and/ or the local anaesthetic could account for the large majority of the serious adverse effects. The reported incidence of inadvertent intravascular injection with fluoroscopically guided TESI is reported to range from $9 \%$ to as high as $32.8 \%[25,189-192]$. This incidence is related to the level at which the injection is performed. Furman et al. [25, 189] reported an incidence of fluoroscopically confirmed intravascular penetration of $19.4 \%$ for cervical TESIs, $8.1 \%$ for lumbar TESIs and $21.3 \%$ for TESIs at the S1 level. In addition, Sullivan et al. [192] suggested that intravascular uptake is twice as likely to occur in patients over rather than under 50 years of age [192]. Vascular embolic events from intra-arterial injection of particulate corticosteroids have been found to account for serious complications including spinal cord infarction, paraplegia and death [93, 100, 102, 103, 105]. Houten et al. [102] presented three cases of paraplegia which ensued suddenly after instillation of the corticosteroid solution in the artery of Adamkiewicz. Similar cases have been reported by others [34]. It should be mentioned that intra-articular injections pose a higher degree of danger, while venous uptake has been considered benign [193, 194]. In terms of the injectate, medium-sized particles between 51 and $1000 \mu \mathrm{m}$ have the potential to enter and occlude a blood vessel [195]. Smaller particles $(10-50 \mu \mathrm{m})$ may still be able to occlude capillaries [195]. Irrespective of the size, it has been suggested that when corticosteroid particles enter a blood vessel they could coalesce and precipitate, forming larger particles [195]. Non-particulate corticosteroids are soluble and should not cause embolic infarction. The injection of the particulate corticosteroid methylprednisolone into the vertebral artery of four pigs resulted in permanent loss of consciousness, while the animals receiving dexamethasone and prednisolone recovered fully [194]. Dawley et al. [193] demonstrated that methylprednisolone and its non-particulate carrier can produce significant injury to the blood-brain barrier when injected intra-arterially. The authors also suggested that in addition to the cerebral microvasculature occlusion by the particulate corticosteroids, damage can occur via toxicity of the carrier or the corticosteroid. Based on several observations that failed to highlight any difference in the efficacy of particulate and non-particulate corticosteroids, we would recommend the use of soluble nonparticulant agents [196-198].

The local anaesthetic, corticosteroid or carrier can cause local and systemic reactions. Blockage of the neural elements by the local anaesthetic can occur. A transient blockage of the neural conduction is expected; however, the reported central canal, conus medularis and cauda 
equina syndromes must have an underlying cause, i.e. hematoma, infarct, etc. Transient systemic reactions including headaches, vasovagal reactions and facial flushing have been reported; these reactions occurred shortly after the ESI and could represent a reaction to the injected anaesthetic agents and/or corticosteroids. It is rather unclear whether ESIs pose a long-term risk of certain conditions and whether a cumulative effect of prolonged exposure exists. If that is true, epidural corticosteroids could have similar systemic effects to that of long-term corticosteroids administered through other routes. For instance, a significant number of the patients with chronic back pain conditions are treated with repeated injections over prolonged period of time. Corticosteroids are known to interfere with calcium homeostasis, reducing bone formation and increasing bone breakdown. Osteoporosis and an increased fracture risk could theoretically occur; however, the available literature does not support this theory. Manchikanti et al. [199] prospectively evaluated 100 patients receiving epidural injections and reported no change in bone mineral density. Insulin resistance is another adverse effect associated with corticosteroid administration; however, studies looking specifically at patients receiving ESIs did not find any changes in the fasting glucose levels [200, 201]. Hypothalamic-pituitaryadrenal axis suppression has been demonstrated to occur after ESIs [200, 202]. Maillefert et al. [200] showed that following ESI with dexamethasone a profound decrease in the serum levels of adrenocorticotropic hormone (ACTH) occurs. These levels of ACTH returned to normal 3 weeks after the injection [200]. Hypertension can also occur following ESIs; a mean systolic blood pressure increase of $5 \mathrm{mmHg}$ has been previously reported following ESIs [201]. Finally, corticosteroid administration represents a risk factor for wound complications postoperatively and poses an increased risk for infections [203]. ESIs are frequently performed prior to spinal surgery, either as a disgnostic tool or for pain management, but their contribution to complications of such procedures is currently unknown.

Severe infections are rare after spinal injections and have an incidence of $0.1-0.01 \%$ [188]. The only exception is a fungal infection outbreak in the USA in 2012. According to the Centers for Disease Control and Prevention, 25 deaths due to epidural corticosteroid-related meningitis (many due to Aspergillosis) were identified: 337 patients were affected in 18 US states and 14,000 patients were probably exposed to contaminated corticosteroids [186].

In the authors' opinion, several recommendations can be made with the aim of minimise the incidence of major complications after ESIs. First, ESIs should be performed under fluoroscopic guidance and the needle position should be confirmed in at least two planes, typically anteroposterior and either an oblique or lateral plane. Intravascular penetration has been the primary concern related to ESIs. Aspiration prior to the injection is specific but not sensitive at detecting intravascular needle placement, being unable to produce a flashback of blood in $74 \%$ of cases in which the needle was ultimately determined to be intravascular [192]. Injection of contrast media is recommended and operators must be able to distinguish between intravascular, epidural and subdural contrast flow patterns. The use of a blunt needle and the suggestion that a small 'test' dose of the medication should be inject initially has been proposed [204-207]. Fluoroscopy can detect unintentional vascular injections [208]. Dynamic live fluoroscopy was found to perform better than static intermittent fluoroscopy, which was found to miss $57 \%$ of the intravascular injections [208]. Digital subtraction angiography can be used as a radiologic adjunct to identify vascular compromise during the injection. However, in a case report by Chang et al. [80], an anaesthetic test dose and digital subtraction angiography performed twice did not prevent a catastrophic spinal cord infarction and the resultant paraplegia. It is under debate whether the transforaminal route poses a higher risk of serious complications when performed by an experience physician. Given the lack of evidence, one could argue that it is reasonable to consider the transforaminal approach only when the interlaminar route has failed. Finally, informed consent should be taken and the patient should be aware of the potential risk and benefits of this procedure.

The survey of cervical injections conducted by Scanlon et al. [41] is the only manuscript that presents a high number of serious and fatal cases. Possible mechanisms explaining these events include the intra-arterial injection of particulate corticosteroid or trauma causing embolisation to the distal basilar or vertebral arteries. Despite the fact that the study presents the extreme end of potential complications, it is unclear what the true incidence of these events is. As previously mentioned, it would be of enormous educational interest to have further details regarding these events, especially details of the technique and imaging used as well as the training and experience of the physician [209].

The warning issued by the FDA regarding ESIs merits further discussion and analysis, and the use of corticosteroids for injections in the epidural space for spinal pain syndromes is not FDA approved. The FDA mentions that, despite their use, the effectiveness of ESIs has been challenged and could potentially result in serious adverse events including death, stroke and paralysis. In support of these arguments, the FDA has published several case reports. Major adverse events can occur with ESIs, but such events are rare, their true incidence is unknown and they have only been presented in case reports. For instance, none of the studies included in Tables 1, 2 and 3 presents 
such major devastating complications. Thus, several authors have criticised the FDA's warning statement as inaccurate. Of note is Manchikanti et al. conclusion stating that the FDA's warning is an additional burden on patient access to pain-relieving treatments [210]. Should the FDA's warning letter be replaced by an evidence-based educational guidance to safeguard the best clinical practice?

Several limitations can be found in the available literature. A large proportion of the available case reports and studies provide insufficient documentation, i.e. the approach used for ESI, symptom duration, volume injected or even the number of injections. In addition, the majority of the studies report adverse effects incidentally as their main aim is to report the efficacy of the injections. Furthermore, the available studies were heterogeneous with regards to the outcome measures, and in several manuscripts the surgical technique, corticosteroid dosage and the addition of other medications are not reported. It is of note that many studies did not look at or record the complications or adverse effects of corticosteroid exposure but present results from several pain and functional scores. Therefore, it is possible that both the short- and long-term adverse effects of corticosteroid exposure remain unreported. As previously highlighted, there is a risk of bias.

\section{Conclusions}

ESIs are relatively safe; however, although major complications of ESIs have been reported, their true incidence remains obscure. Vascular penetration and administration of pharmaceutical agents intra-arterially could account for a large proportion of the adverse events reported. With accurate placement of the needle, use of non-particulate corticosteroids, live fluoroscopy, digital subtraction angiography and familiarisation of the contrast patterns on fluoroscopy these risks should be minimised. Further research is required to shed more light on the best clinical practice for the use of ESIs and the true incidence of complications relating to them.

\section{Compliance with Ethical Standards}

No funding was received for the preparation of this manuscript. IP, MP, GW, DB, and PVG have no conflicts of interest to declare.

Open Access This article is distributed under the terms of the Creative Commons Attribution-NonCommercial 4.0 International License (http://creativecommons.org/licenses/by-nc/4.0/), which permits any noncommercial use, distribution, and reproduction in any medium, provided you give appropriate credit to the original author(s) and the source, provide a link to the Creative Commons license, and indicate if changes were made.

\section{References}

1. Muramoto T, Atsuta Y, Iwahara T, Sato M, Takemitsu Y. The action of prostaglandin E2 and triamcinolone acetonide on the firing activity of lumbar nerve roots. Int Orthop. 1997;21:172-5.

2. Di Donato A, Fontana C, Alemanno D, Di Giacomo A. Epiduroscopy in treatment of degenerative chronic low back pain: a prospective analysis and follow-up at 60 months. Clin Res Regul Aff. 2010;27:69-74.

3. Whitlock EL, Bridwell KH, Gilula LA. Influence of needle tip position on injectate spread in 406 interlaminar lumbar epidural steroid injections. Radiology. 2007;243:804-11.

4. Lee JH, An JH, Lee SH. Comparison of the effectiveness of interlaminar and bilateral transforaminal epidural steroid injections in treatment of patients with lumbosacral disc herniation and spinal stenosis. Clin J Pain. 2009;25:206-10.

5. Chang-Chien GC, Knezevic NN, McCormick Z, Chu SK, Trescot AM, Candido KD. Transforaminal versus interlaminar approaches to epidural steroid injections: a systematic review of comparative studies for lumbosacral radicular pain. Pain Physician. 2014;17:E509-24.

6. Rados I, Sakic K, Fingler M, Kapural L. Efficacy of interlaminar vs transforaminal epidural steroid injection for the treatment of chronic unilateral radicular pain: prospective, randomized study. Pain Med. 2011;12:1316-21.

7. Bui J, Bogduk N. A systematic review of the effectiveness of CT-guided, lumbar transforaminal injection of steroids. Pain Med. 2013;14:1860-5.

8. Gofeld M, Bristow SJ, Chiu SC, McQueen CK, Bollag L. Ultrasound-guided lumbar transforaminal injections: feasibility and validation study. Spine (Phila Pa 1976). 2012;37:808-12.

9. Chou R, Atlas SJ, Stanos SP, Rosenquist RW. Nonsurgical interventional therapies for low back pain: a review of the evidence for an American Pain Society clinical practice guideline. Spine (Phila Pa 1976). 2009;34:1078-93.

10. Friedly JL, Comstock BA, Turner JA, Heagerty PJ, Deyo RA, Sullivan SD, et al. A randomized trial of epidural glucocorticoid injections for spinal stenosis. N Engl J Med. 2014;371:11-21.

11. Pinto RZ, Maher CG, Ferreira ML, Hancock M, Oliveira VC, McLachlan AJ, et al. Epidural corticosteroid injections in the management of sciatica: a systematic review and meta-analysis. Ann Intern Med. 2012;157:865-77.

12. Staal JB, de Bie RA, de Vet HC, Hildebrandt J, Nelemans P. Injection therapy for subacute and chronic low back pain: an updated Cochrane review. Spine (Phila Pa 1976). 2009;34: 49-59.

13. Benny B, Azari P. The efficacy of lumbosacral transforaminal epidural steroid injections: a comprehensive literature review. J Back Musculoskelet Rehabil. 2011;24:67-76.

14. Benyamin RM, Singh V, Parr AT, Conn A, Diwan S, Abdi S. Systematic review of the effectiveness of cervical epidurals in the management of chronic neck pain. Pain Physician. 2009;12:137-57.

15. Diwan S, Manchikanti L, Benyamin RM, Bryce DA, Geffert S, Hameed $\mathrm{H}$, et al. Effectiveness of cervical epidural injections in the management of chronic neck and upper extremity pain. Pain Physician. 2012;15:E405-34.

16. MacVicar J, King W, Landers MH, Bogduk N. The effectiveness of lumbar transforaminal injection of steroids: a comprehensive review with systematic analysis of the published data. Pain Med. 2013;14:14-28.

17. Manchikanti L, Falco FJ, Diwan S, Hirsch JA, Smith HS. Cervical radicular pain: the role of interlaminar and transforaminal epidural injections. Curr Pain Headache Rep. 2014;18:389. 
18. Quraishi NA. Transforaminal injection of corticosteroids for lumbar radiculopathy: systematic review and meta-analysis. Eur Spine J. 2012;21:214-9.

19. US Food and Drug Administration. FDA Drug Safety Communication: FDA requires label changes to warn of rare but serious neurologic problems after epidural corticosteroid injections for pain. 2014. http://www.fda.gov/downloads/Drugs/ DrugSafety/UCM394286.pdf. Accessed 13 Dec 2015.

20. Moher D, Liberati A, Tetzlaff J, Altman DG, Group P. Preferred reporting items for systematic reviews and meta-analyses: the PRISMA statement. BMJ. 2009;339:b2535.

21. Beyaz SG, Eman A. Fluoroscopy guided cervical interlaminar steroid injections in patients with cervical pain syndromes: a retrospective study. J Back Musculoskelet Rehabil. 2013;26: 85-91.

22. Botwin KP, Castellanos R, Rao S, Hanna AF, Torres-Ramos FM, Gruber RD, et al. Complications of fluoroscopically guided interlaminar cervical epidural injections. Arch Phys Med Rehabil. 2003;84:627-33.

23. Castagnera L, Maurette P, Pointillart V, Vital JM, Erny P, Senegas J. Long-term results of cervical epidural steroid injection with and without morphine in chronic cervical radicular pain. Pain. 1994;58:239-43.

24. Derby R, Lee SH, Kim BJ, Chen Y, Seo KS. Complications following cervical epidural steroid injections by expert interventionalists in 2003. Pain Physician. 2004;7:445-9.

25. Furman MB, Giovanniello MT, O'Brien EM. Incidence of intravascular penetration in transforaminal cervical epidural steroid injections. Spine (Phila Pa 1976). 2003;28:21-5.

26. Goel A, Pollan JJ. Contrast flow characteristics in the cervical epidural space: an analysis of cervical epidurograms. Spine (Phila Pa 1976). 2006;31:1576-9.

27. Kolstad F, Leivseth G, Nygaard OP. Transforaminal steroid injections in the treatment of cervical radiculopathy. A prospective outcome study. Acta Neurochir (Wien). 2005;147:1065-70 (discussion 1070).

28. Kranz PG, Raduazo P, Gray L, Kilani RK, Hoang JK. CT fluoroscopy-guided cervical interlaminar steroid injections: safety, technique, and radiation dose parameters. AJNR Am J Neuroradiol. 2012;33:1221-4.

29. Kwon JW, Lee JW, Kim SH, Choi JY, Yeom JS, Kim HJ, et al. Cervical interlaminar epidural steroid injection for neck pain and cervical radiculopathy: effect and prognostic factors. Skeletal Radiol. 2007;36:431-6.

30. Lee JW, Hwang SY, Lee GY, Lee E, Kang HS. Fluoroscopic cervical paramidline interlaminar epidural steroid injections for cervical radiculopathy: effectiveness and outcome predictors. Skeletal Radiol. 2014;43:933-8.

31. Lee SH, Kim KT, Kim DH, Lee BJ, Son ES, Kwack YH. Clinical outcomes of cervical radiculopathy following epidural steroid injection: a prospective study with follow-up for more than 2 years. Spine (Phila Pa 1976). 2012;37:1041-7.

32. Manchikanti L, Cash KA, Pampati V, Malla Y. Two-year follow-up results of fluoroscopic cervical epidural injections in chronic axial or discogenic neck pain: a randomized, doubleblind, controlled trial. Int J Med Sci. 2014;11:309-20.

33. Manchikanti L, Cash KA, Pampati V, Wargo BW, Malla Y. A randomized, double-blind, active control trial of fluoroscopic cervical interlaminar epidural injections in chronic pain of cervical disc herniation: results of a 2 -year follow-up. Pain Physician. 2013;16:465-78.

34. Manchikanti L, Malla Y, Wargo BW, Cash KA, Pampati V, Fellows B. A prospective evaluation of complications of 10,000 fluoroscopically directed epidural injections. Pain Physician. 2012;15:131-40.
35. Candido KD, Rana MV, Sauer R, Chupatanakul L, Tharian A, Vasic V, et al. Concordant pressure paresthesia during interlaminar lumbar epidural steroid injections correlates with pain relief in patients with unilateral radicular pain. Pain Physician. 2013;16:497-511.

36. Carette S, Leclaire R, Marcoux S, Morin F, Blaise GA, St-Pierre A, et al. Epidural corticosteroid injections for sciatica due to herniated nucleus pulposus. N Engl J Med. 1997;336:1634-40.

37. Kloth DS, Calodney AK, Derby R, Lagattuta FP, O'Neill C, Yurth E, et al. Improving the safety of transforaminal epidural steroid injections in the treatment of cervical radiculopathy. Pain Physician. 2011;14:285-93.

38. Lee JW, Park KW, Chung SK, Yeom JS, Kim KJ, Kim HJ, et al. Cervical transforaminal epidural steroid injection for the management of cervical radiculopathy: a comparative study of particulate versus non-particulate steroids. Skeletal Radiol. 2009;38:1077-82.

39. Lin EL, Lieu V, Halevi L, Shamie AN, Wang JC. Cervical epidural steroid injections for symptomatic disc herniations. J Spinal Disord Tech. 2006;19:183-6.

40. Manchikanti L, Cash KA, McManus CD, Damron KS, Pampati V, Falco FJ. Lumbar interlaminar epidural injections in central spinal stenosis: preliminary results of a randomized, doubleblind, active control trial. Pain Physician. 2012;15:51-63.

41. Scanlon GC, Moeller-Bertram T, Romanowsky SM, Wallace MS. Cervical transforaminal epidural steroid injections: more dangerous than we think? Spine (Phila Pa 1976). 2007;32: 1249-56.

42. Valat JP, Giraudeau B, Rozenberg S, Goupille P, Bourgeois P, Micheau-Beaugendre V, et al. Epidural corticosteroid injections for sciatica: a randomised, double blind, controlled clinical trial. Ann Rheum Dis. 2003;62:639-43.

43. Vallee JN, Feydy A, Carlier RY, Mutschler C, Mompoint D, Vallee CA. Chronic cervical radiculopathy: lateral-approach periradicular corticosteroid injection. Radiology. 2001;218:886-92.

44. Arden NK, Price C, Reading I, Stubbing J, Hazelgrove J, Dunne C, WEST Study Group, et al. A multicentre randomized controlled trial of epidural corticosteroid injections for sciatica: the WEST study. Rheumatology (Oxford). 2005;44:1399-406.

45. Bartynski WS, Jennings RB, Rothfus WE, Agarwal V. Immediate pain response to interlaminar lumbar epidural steroid administration: response characteristics and effects of anesthetic concentration. AJNR Am J Neuroradiol. 2013;34:239-46.

46. Candido KD, Katz JA, Chinthagada M, McCarthy RA, Knezevic $\mathrm{NN}$. Incidence of intradiscal injection during lumbar fluoroscopically guided transforaminal and interlaminar epidural steroid injections. Anesth Analg. 2010;110:1464-7.

47. Evansa I, Logina I, Vanags I, Borgeat A. Ultrasound versus fluoroscopic-guided epidural steroid injections in patients with degenerative spinal diseases: a randomised study. Eur J Anaesthesiol. 2015;32:262-8.

48. Huang AJ, Rosenthal DI, Palmer WE. Inadvertent intra-articular lumbar facet joint injection during fluoroscopically guided interlaminar epidural steroid injection. Skeletal Radiol. 2011;40:33-45.

49. Kim CH, Issa MA, Vaglienti RM. Flushing following interlaminar lumbar epidural steroid injection with dexamethasone. Pain Physician. 2010;13:481-4.

50. Kim D, Brown J. Efficacy and safety of lumbar epidural dexamethasone versus methylprednisolone in the treatment of lumbar radiculopathy: a comparison of soluble versus particulate steroids. Clin J Pain. 2011;27:518-22.

51. Kraemer J, Ludwig J, Bickert U, Owczarek V, Traupe M. Lumbar epidural perineural injection: a new technique. Eur Spine J. 1997;6:357-61. 
52. Manchikanti L, Falco FJ, Pampati V, Hirsch JA. Lumbar interlaminar epidural injections are superior to caudal epidural injections in managing lumbar central spinal stenosis. Pain Physician. 2014;17:E691-702.

53. Botwin KP, Gruber RD, Bouchlas CG, Torres-Ramos FM, Freeman TL, Slaten WK. Complications of fluoroscopically guided transforaminal lumbar epidural injections. Arch Phys Med Rehabil. 2000;81:1045-50.

54. Gelalis ID, Arnaoutoglou E, Pakos EE, Politis AN, Rapti M, Xenakis TA, et al. Effect of interlaminar epidural steroid injection in acute and subacute pain due to lumbar disk herniation: a randomized comparison of 2 different protocols. Open Orthop J. 2009;3:121-4.

55. Ghai B, Vadaje KS, Wig J, Dhillon MS. Lateral parasagittal versus midline interlaminar lumbar epidural steroid injection for management of low back pain with lumbosacral radicular pain: a double-blind, randomized study. Anesth Analg. 2013;117: 219-27.

56. Hong JH, Lee SM, Bae JH. Analysis of inadvertent intradiscal injections during lumbar transforaminal epidural injection. Korean J Pain. 2014;27:168-73.

57. Karaman H, Kavak GO, Tufek A, Yldrm ZB. The complications of transforaminal lumbar epidural steroid injections. Spine (Phila Pa 1976). 2011;36:E819-24.

58. Manson NA, McKeon MD, Abraham EP. Transforaminal epidural steroid injections prevent the need for surgery in patients with sciatica secondary to lumbar disc herniation: a retrospective case series. Can J Surg. 2013;56:89-96.

59. McGrath JM, Schaefer MP, Malkamaki DM. Incidence and characteristics of complications from epidural steroid injections. Pain Med. 2011;12:726-31.

60. Milburn J, Freeman J, Steven A, Altmeyer W, Kay D. Interlaminar epidural steroid injection for degenerative lumbar spinal canal stenosis: does the intervertebral level of performance matter? Ochsner J. 2014;14:62-6.

61. Ploumis A, Christodoulou P, Wood KB, Varvarousis D, Sarni $\mathrm{JL}$, Beris A. Caudal vs transforaminal epidural steroid injections as short-term (6 months) pain relief in lumbar spinal stenosis patients with sciatica. Pain Med. 2014;15:379-85.

62. Ahadian FM, McGreevy K, Schulteis G. Lumbar transforaminal epidural dexamethasone: a prospective, randomized, doubleblind, dose-response trial. Reg Anesth Pain Med. 2011;36: $572-8$.

63. Cansever T, Kabatas S, Civelek E, Kircelli A, Yilmaz C, Musluman M, et al. Transforaminal epidural steroid injection via a preganglionic approach for the treatment of lumbar radicular pain. Turk Neurosurg. 2012;22:183-8.

64. Kim HJ, Rim BC, Lim JW, Park NK, Kang TW, Sohn MK, et al. Efficacy of epidural neuroplasty versus transforaminal epidural steroid injection for the radiating pain caused by a herniated lumbar disc. Ann Rehabil Med. 2013;37:824-31.

65. Koh WU, Choi SS, Park SY, Joo EY, Kim SH, Lee JD, et al. Transforaminal hypertonic saline for the treatment of lumbar lateral canal stenosis: a double-blinded, randomized, activecontrol trial. Pain Physician. 2013;16:197-211.

66. Kraiwattanapong C, Wechmongkolgorn S, Chatriyanuyok B, Woratanarat $\mathrm{P}$, Udomsubpayakul U, Chanplakorn $\mathrm{P}$, et al. Outcomes of fluoroscopically guided lumbar transforaminal epidural steroid injections in degenerative lumbar spondylolisthesis patients. Asian Spine J. 2014;8:119-28.

67. Manchikanti L, Cash KA, Pampati V, Falco FJ. Transforaminal epidural injections in chronic lumbar disc herniation: a randomized, double-blind, active-control trial. Pain Physician. 2014; 17:E489-501.

68. Tauheed N, Usmani H, Siddiqui AH. A comparison of the analgesic efficacy of transforaminal methylprednisolone alone and with low doses of clonidine in lumbo-sacral radiculopathy. Saudi J Anaesth. 2014;8:51-8.

69. Wewalka M, Abdelrahimsai A, Wiesinger GF, Uher EM. CTguided transforaminal epidural injections with local anesthetic, steroid, and tramadol for the treatment of persistent lumbar radicular pain. Pain Physician. 2012;15:153-9.

70. Ackerman WE 3rd, Ahmad M. The efficacy of lumbar epidural steroid injections in patients with lumbar disc herniations. Anesth Analg. 2007;104:1217-22.

71. Botwin KP, Gruber RD, Bouchlas CG, Torres-Ramos FM, Sanelli JT, Freeman ED, et al. Fluoroscopically guided lumbar transformational epidural steroid injections in degenerative lumbar stenosis: an outcome study. Am J Phys Med Rehabil. 2002;81:898-905.

72. Jeong HS, Lee JW, Kim SH, Myung JS, Kim JH, Kang HS. Effectiveness of transforaminal epidural steroid injection by using a preganglionic approach: a prospective randomized controlled study. Radiology. 2007;245:584-90.

73. Kabatas S, Cansever T, Yilmaz C, Kocyigit OI, Coskun E, Demircay E, et al. Transforaminal epidural steroid injection via a preganglionic approach for lumbar spinal stenosis and lumbar discogenic pain with radiculopathy. Neurol India. 2010;58:248-52.

74. Lutz GE, Vad VB, Wisneski RJ. Fluoroscopic transforaminal lumbar epidural steroids: an outcome study. Arch Phys Med Rehabil. 1998;79:1362-6.

75. Rahimzadeh P, Sharma V, Imani F, Faiz HR, Ghodraty MR, Nikzad-Jamnani AR, et al. Adjuvant hyaluronidase to epidural steroid improves the quality of analgesia in failed back surgery syndrome: a prospective randomized clinical trial. Pain Physician. 2014; 17:E75-82.

76. Roy C, Chatterjee N, Patro SN, Chakraborty A, Vijay Kumar GR, Sengupta R. The efficacy of transforaminal epidural steroid injections in lumbosacral radiculopathy. Neurol India. 2011;59:685-9.

77. Vad VB, Bhat AL, Lutz GE, Cammisa F. Transforaminal epidural steroid injections in lumbosacral radiculopathy: a prospective randomized study. Spine (Phila Pa 1976). 2002;27:11-6.

78. Yang SC, Fu TS, Lai PL, Niu CC, Chen LH, Chen WJ. Transforaminal epidural steroid injection for discectomy candidates: an outcome study with a minimum of two-year followup. Chang Gung Med J. 2006;29:93-9.

79. AbdeleRahman KT, Rakocevic G. Paraplegia following lumbosacral steroid epidural injections. J Clin Anesth. 2014;26:497-9.

80. Chang Chien GC, Candido KD, Knezevic NN. Digital subtraction angiography does not reliably prevent paraplegia associated with lumbar transforaminal epidural steroid injection. Pain Physician. 2012;15:515-23.

81. Desai MJ, Dua S. Perineural hematoma following lumbar transforaminal steroid injection causing acute-on-chronic lumbar radiculopathy: a case report. Pain Pract. 2014;14:271-7.

82. Kim W, Kim JS, Lim SC, Kim YI, Moon DE. Reversible posterior leukoencephalopathy syndrome after cervical transforaminal epidural steroid injection presenting as transient blindness. Anesth Analg. 2011;112:967-70.

83. Kushner FH, Olson JC. Retinal hemorrhage as a consequence of epidural steroid injection. Arch Ophthalmol. 1995;113:309-13.

84. McMillan MR, Crumpton C. Cortical blindness and neurologic injury complicating cervical transforaminal injection for cervical radiculopathy. Anesthesiology. 2003;99:509-11.

85. Popescu A, Lai D, Lu A, Gardner K. Stroke following epidural injections-case report and review of literature. J Neuroimaging. 2013;23:118-21.

86. Purdy EP, Ajimal GS. Vision loss after lumbar epidural steroid injection. Anesth Analg. 1998;86:119-22. 
87. Young WF. Transient blindness after lumbar epidural steroid injection: a case report and literature review. Spine (Phila $\mathrm{Pa}$ 1976). 2002;27:E476-7.

88. Beckman WA, Mendez RJ, Paine GF, Mazzilli MA. Cerebellar herniation after cervical transforaminal epidural injection. Reg Anesth Pain Med. 2006;31:282-5.

89. Brouwers PJ, Kottink EJ, Simon MA, Prevo RL. A cervical anterior spinal artery syndrome after diagnostic blockade of the right C6-nerve root. Pain. 2001;91:397-9.

90. Kim WJ, Park HG, Park YH, Shin MR, Koo GH, Shin HY. Pneumocephalus during cervical transforaminal epidural steroid injections: a case report. Am J Phys Med Rehabil. 2015;94:63-9.

91. Ludwig MA, Burns SP. Spinal cord infarction following cervical transforaminal epidural injection: a case report. Spine (Phila $\mathrm{Pa}$ 1976). 2005;30:E266-8.

92. Muro K, O'Shaughnessy B, Ganju A. Infarction of the cervical spinal cord following multilevel transforaminal epidural steroid injection: case report and review of the literature. J Spinal Cord Med. 2007;30:385-8.

93. Rozin L, Rozin R, Koehler SA, Shakir A, Ladham S, Barmada $\mathrm{M}$, et al. Death during transforaminal epidural steroid nerve root block (C7) due to perforation of the left vertebral artery. Am J Forensic Med Pathol. 2003;24:351-5.

94. Sweni S, Senthilkumaran S, Balamurugan N, Thirumalaikolundusubramanian P. Tension pneumocephalus: a case report with review of literature. Emerg Radiol. 2013;20:573-8.

95. Sykes KT, Yi X. Intracranial hypotension headache caused by a massive cerebrospinal fluid leak successfully treated with a targeted c2 epidural blood patch: a case report. Pain Physician. 2013;16:399-404.

96. Thefenne L, Dubecq C, Zing E, Rogez D, Soula M, Escobar E, et al. A rare case of paraplegia complicating a lumbar epidural infiltration. Ann Phys Rehabil Med. 2010;53:575-83.

97. Ziai WC, Ardelt AA, Llinas RH. Brainstem stroke following uncomplicated cervical epidural steroid injection. Arch Neurol. 2006;63:1643-6.

98. De Oliveira GS, Jr Charchaflieh J, Walega D Jr. Pneumorrhachis mimicking meningitis after a paramedian lumbar interlaminar injection. Clin J Pain. 2011;27:355-6.

99. Gitkind AI, Shah B, Thomas M. Epidural corticosteroid injections as a possible cause of menorrhagia: a case report. Pain Med. 2010;11:713-5.

100. Glaser SE, Falco F. Paraplegia following a thoracolumbar transforaminal epidural steroid injection. Pain Physician. 2005;8:309-14.

101. Hirsch JG, Hsu ES. Abnormal uterine bleeding following lumbar epidural corticosteroid injections and facet medial branch blocks in both pre- and postmenopausal women: a case series. Pain Med. 2012;13:1137-40.

102. Houten JK, Errico TJ. Paraplegia after lumbosacral nerve root block: report of three cases. Spine J. 2002;2:70-5.

103. Huntoon MA, Martin DP. Paralysis after transforaminal epidural injection and previous spinal surgery. Reg Anesth Pain Med. 2004;29:494-5.

104. Kao LY. Bilateral serous retinal detachment resembling central serous chorioretinopathy following epidural steroid injection. Retina. 1998;18:479-81.

105. Kennedy DJ, Dreyfuss P, Aprill CN, Bogduk N. Paraplegia following image-guided transforaminal lumbar spine epidural steroid injection: two case reports. Pain Med. 2009;10:1389-94.

106. Suresh S, Berman J, Connell DA. Cerebellar and brainstem infarction as a complication of CT-guided transforaminal cervical nerve root block. Skeletal Radiol. 2007;36:449-52.

107. Wybier M, Gaudart S, Petrover D, Houdart E, Laredo JD. Paraplegia complicating selective steroid injections of the lumbar spine. Report of five cases and review of the literature. Eur Radiol. 2010;20:181-9.

108. Centers for Disease Control and Prevention (CDC). Spinal and paraspinal infections associated with contaminated methylprednisolone acetate injections-Michigan, 2012-2013. MMWR Morb Mortal Wkly Rep. 2013;62:377-81.

109. Chiller TM, Roy M, Nguyen D, Guh A, Malani AN, Latham R, Multistate Fungal Infection Clinical Investigation Team, et al. Clinical findings for fungal infections caused by methylprednisolone injections. N Engl J Med. 2013;369:1610-9.

110. Dunn LT, Javed A, Findlay G, Green AD. Iatrogenic spinal infection following epidural anaesthesia: case report. Eur Spine J. 1996;5:418-20.

111. Gaul C, Neundorfer B, Winterholler M. Iatrogenic (para-) spinal abscesses and meningitis following injection therapy for low back pain. Pain. 2005;116:407-10.

112. Kabbara A, Rosenberg SK, Untal C. Methicillin-resistant Staphylococcus aureus epidural abscess after transforaminal epidural steroid injection. Pain Physician. 2004;7:269-72.

113. Kolbe AB, McKinney AM, Kendi AT, Misselt D. Aspergillus meningitis and discitis from low-back procedures in an immunocompetent patient. Acta Radiol. 2007;48:687-9.

114. Saigal G, Donovan Post MJ, Kozic D. Thoracic intradural Aspergillus abscess formation following epidural steroid injection. AJNR Am J Neuroradiol. 2004;25:642-4.

115. Shanthanna H, Busse JW. Abnormal vaginal bleeding after epidural steroid injection: is there a cause for concern? Evid Based Med. 2014;19:e16.

116. Suh-Burgmann E, Hung YY, Mura J. Abnormal vaginal bleeding after epidural steroid injection: a paired observation cohort study. Am J Obstet Gynecol. 2013;209(206):e1-6.

117. Davis K, Prater A, Fluker SA, Klein R. A difficult case to swallow: herpes esophagitis after epidural steroid injection. Am J Ther. 2014;21:e9-14.

118. Hooten WM, Kinney MO, Huntoon MA. Epidural abscess and meningitis after epidural corticosteroid injection. Mayo Clin Proc. 2004;79:682-6.

119. Huang RC, Shapiro GS, Lim M, Sandhu HS, Lutz GE, Herzog RJ. Cervical epidural abscess after epidural steroid injection. Spine (Phila Pa 1976). 2004;29:E7-9.

120. Kaul S, Meena AK, Sundaram C, Reddy JM, Naik RT, Murthy JM. Spinal extradural abscess following local steroid injection. Neurol India. 2000;48:181-3.

121. Koka VK, Potti A. Spinal epidural abscess after corticosteroid injections. South Med J. 2002;95:772-4.

122. Kraeutler MJ, Bozzay JD, Walker MP, John K. Spinal subdural abscess following epidural steroid injection. J Neurosurg Spine. 2015;22:90-3.

123. Lindner A, Warmuth-Metz M, Becker G, Toyka VV. Iatrogenic spinal epidural abscesses: early diagnosis essential for good outcome. Eur J Med Res. 1997;2:201-5.

124. Reitman CA, Watters W 3rd. Subdural hematoma after cervica epidural steroid injection. Spine (Phila Pa 1976). 2002;27:E174-6.

125. Sato S, Sakuragi T, Dan K. Human skin flora as a potential source of epidural abscess. Anesthesiology. 1996;85:1276-82.

126. Simopoulos TT, Kraemer JJ, Glazer P, Bajwa ZH. Vertebral osteomyelitis: a potentially catastrophic outcome after lumbar epidural steroid injection. Pain Physician. 2008;11:693-7.

127. Trautmann M, Lepper PM, Schmitz FJ. Three cases of bacterial meningitis after spinal and epidural anesthesia. Eur J Clin Microbiol Infect Dis. 2002;21:43-5.

128. Abbasi A, Roque-Dang CM, Malhotra G. Persistent hiccups after interventional pain procedures: a case series and review. PM R. 2012;4:144-51.

129. Chung SG. Convulsion caused by a lidocaine test in cervical transforaminal epidural steroid injection. PM R. 2011;3:674-7. 
130. Cooper AB, Sharpe MD. Bacterial meningitis and cauda equina syndrome after epidural steroid injections. Can J Anaesth. 1996;43:471-4.

131. Grierson MJ, Harrast MA. Iatrogenic Cushing syndrome after epidural steroid injections for lumbar radiculopathy in an HIVinfected patient treated with ritonavir: a case report highlighting drug interactions for spine interventionalists. PM R. 2012;4:234-7.

132. Knight JW, Cordingley JJ, Palazzo MG. Epidural abscess following epidural steroid and local anaesthetic injection. Anaesthesia. 1997;52:576-8.

133. Maeder PP, Ingvar-Maeder MC, Meuli RA, Regli F, de Tribolet N. Cervical epidural abscess due to actinomycosis: demonstration by MRI. Eur Neurol. 1996;36:56-7.

134. Moran DE, Moynagh MR, Alzanki M, Chan VO, Eustace SJ. Anaphylaxis at image-guided epidural pain block secondary to corticosteroid compound. Skeletal Radiol. 2012;41:1317-8.

135. Shanthanna H, Park J. Acute epidural haematoma following epidural steroid injection in a patient with spinal stenosis. Anaesthesia. 2011;66:837-9.

136. Stauber B, Ma L, Nazari R. Cardiopulmonary arrest following cervical epidural injection. Pain Physician. 2012;15:147-52.

137. Benyamin RM, Vallejo R, Kramer J, Rafeyan R. Corticosteroid induced psychosis in the pain management setting. Pain Physician. 2008;11:917-20.

138. Danielson KD, Harrast MA. Focal spinal epidural lipomatosis after a single epidural steroid injection. PM R. 2011;3:590-3.

139. Goodman BS, Bayazitoglu M, Mallempati S, Noble BR, Geffen JF. Dural puncture and subdural injection: a complication of lumbar transforaminal epidural injections. Pain Physician. 2007;10:697-705.

140. Lee JH, Lee JK, Seo BR, Moon SJ, Kim JH, Kim SH. Spinal cord injury produced by direct damage during cervical transforaminal epidural injection. Reg Anesth Pain Med. 2008;33:377-9.

141. Linn AJ, Desilva C, Peeters-Asdourian C. Thromboembolic stroke: a rare complication associated with peri-procedural management of an epidural steroid injection. Pain Physician. 2009;12:159-62.

142. Ozdemir O, Calisaneller T, Yildirim E, Altinors N. Acute intracranial subdural hematoma after epidural steroid injection: a case report. J Manip Physiol Ther. 2007;30:536-8.

143. Tok CH, Kaur S, Gangi A. Symptomatic spinal epidural lipomatosis after a single local epidural steroid injection. Cardiovasc Intervent Radiol. 2011;34(Suppl 2):S250-5.

144. Xu R, Bydon M, Gokaslan ZL, Wolinsky JP, Witham TF, Bydon A. Epidural steroid injection resulting in epidural hematoma in a patient despite strict adherence to anticoagulation guidelines. J Neurosurg Spine. 2009;11:358-64.

145. Yoo HS, Park SW, Han JH, Chung JY, Yi JW, Kang JM, et al. Paraplegia caused by an epidural hematoma in a patient with unrecognized chronic idiopathic thrombocytopenic purpura following an epidural steroid injection. Spine (Phila Pa 1976). 2009;34:E376-9.

146. Ain RJ, Vance MB. Epidural hematoma after epidural steroid injection in a patient withholding enoxaparin per guidelines. Anesthesiology. 2005;102:701-3.

147. Ammirati M, Perino F. Symptomatic air trapped in the spine after lumbar epidural corticosteroid injection. Case report. J Neurosurg Spine. 2006;5:359-61.

148. Bilir A, Gulec S. Cauda equina syndrome after epidural steroid injection: a case report. J Manip Physiol Ther. 2006;29(492): e1-3.

149. Bose B. Quadriparesis following cervical epidural steroid injections: case report and review of the literature. Spine J. 2005;5:558-63.
150. Dietrich CL, Smith CE. Epidural granuloma and intracranial hypotension resulting from cervical epidural steroid injection. Anesthesiology. 2004;100:445-7.

151. Hawley JS, Ney JP, Swanberg MM. Subarachnoid pneumocephalus from epidural steroid injection. Headache. 2005;45: 247-8.

152. McAllister RK, McDavid AJ, Meyer TA, Bittenbinder TM. Recurrent persistent hiccups after epidural steroid injection and analgesia with bupivacaine. Anesth Analg. 2005;100:1834-6.

153. McLain RF, Fry M, Hecht ST. Transient paralysis associated with epidural steroid injection. J Spinal Disord. 1997;10:441-4.

154. Pizzimenti JJ, Daniel KP. Central serous chorioretinopathy after epidural steroid injection. Pharmacotherapy. 2005;25:1141-6.

155. Snarr J. Risk, benefits and complications of epidural steroid injections: a case report. AANA J. 2007;75:183-8.

156. Tripathi M, Nath SS, Gupta RK. Paraplegia after intracord injection during attempted epidural steroid injection in an awakepatient. Anesth Analg. 2005;101:1209-11 (table of contents).

157. Bansal S, Turtle MJ. Inadvertent subdural spread complicating cervical epidural steroid injection with local anaesthetic agent. Anaesth Intensive Care. 2003;31:570-2.

158. Field J, Rathmell JP, Stephenson JH, Katz NP. Neuropathic pain following cervical epidural steroid injection. Anesthesiology. 2000;93:885-8.

159. Ghaly RF. Recovery after high-dose methylprednisolone and delayed evacuation: a case of spinal epidural hematoma. J Neurosurg Anesthesiol. 2001;13:323-8.

160. Hodges SD, Castleberg RL, Miller T, Ward R, Thornburg C. Cervical epidural steroid injection with intrinsic spinal cord damage. Two case reports. Spine (Phila Pa 1976). 1998;23:2137-42 (discussion 2141-2).

161. McCullen GM, Spurling GR, Webster JS. Epidural lipomatosis complicating lumbar steroid injections. J Spinal Disord. 1999;12:526-9.

162. Siddiqui MN, Ranasinghe JS, Siddiqui S. Epidural hematoma after epidural steroid injection: a possible association with use of pentosan polysulfate sodium. Anesthesiology. 2001;95:1307.

163. Siegfried RN. Development of complex regional pain syndrome after a cervical epidural steroid injection. Anesthesiology. 1997;86:1394-6.

164. Stoll A, Sanchez M. Epidural hematoma after epidural block: implications for its use in pain management. Surg Neurol. 2002;57:235-40.

165. Szokol JW, Gilbert HC. A herpes zoster outbreak temporarily associated with an epidural steroid injection. Reg Anesth Pain Med. 1998;23:328.

166. Boonen S, Van Distel G, Westhovens R, Dequeker J. Steroid myopathy induced by epidural triamcinolone injection. $\mathrm{Br} \mathrm{J}$ Rheumatol. 1995;34:385-6.

167. Browning DJ. Acute retinal necrosis following epidural steroid injections. Am J Ophthalmol. 2003;136:192-4.

168. Chien GC, McCormick Z, Araujo M, Candido KD. The potential contributing effect of ketorolac and fluoxetine to a spinal epidural hematoma following a cervical interlaminar epidural steroid injection: a case report and narrative review. Pain Physician. 2014;17:E385-95.

169. El Abd O, Pimentel DC, Amadera JE. Generalized pruritus as an unusual side effect after epidural injection with dexamethasone. PM R. 2015;7:206-9.

170. Ergenoglu P, Bali C, Akin S, Ozyilkan NB, Aribogan A. Pneumorrhachis and pneumocephalus with severe chest pain symptom: a rare complication of epidural steroid injection. Pain Med. 2014;15:1239-40.

171. Kalia H. An unusual case of ASIA C T-10 paraplegia after lumbar transforaminal epidural steroid injection. $\mathrm{J}$ Pain. 2014;15:S99. 
172. Maddela R, Wahezi SE, Sparr S, Brook A. Hemiparesis and facial sensory loss following cervical epidural steroid injection. Pain Physician. 2014;17:E761-7.

173. Morelli JN, Porbandarwala N, Patel DV. Spinal cord needle tract following epidural steroid injection. J Vasc Interv Radiol. 2012;23:1543-4.

174. Obeid TH, Gornas MA, El-Mesallamy AA. Spinal cord ischemia following cervical transforaminal epidural steroid injection. Neurosciences (Riyadh). 2014;19:326-7.

175. Park CH, Shin YH, Lee SH. Dermatomal skin rash after lumbar epidural steroid injection. Clin J Pain. 2011;27:163-5.

176. Tiso RL, Cutler T, Catania JA, Whalen K. Adverse central nervous system sequelae after selective transforaminal block: the role of corticosteroids. Spine J. 2004;4:468-74.

177. Wallace MA, Fukui MB, Williams RL, Ku A, Baghai P. Complications of cervical selective nerve root blocks performed with fluoroscopic guidance. AJR Am J Roentgenol. 2007; 188:1218-21.

178. Windsor RE, Storm S, Sugar R, Nagula D. Cervical transforaminal injection: review of the literature, complications, and a suggested technique. Pain Physician. 2003;6:457-65.

179. Yue WM, Tan SB. Distant skip level discitis and vertebral osteomyelitis after caudal epidural injection: a case report of a rare complication of epidural injections. Spine (Phila $\mathrm{Pa}$ 1976). 2003;28:E209-11.

180. Lievre J, Bloch M, Pean G, Uno J. L'hydrocortisone en injection local. Rev Rhum Mal Osteoartic. 1953;20:300-301.

181. Manchikanti L, Pampati V, Boswell MV, Smith HS, Hirsch JA. Analysis of the growth of epidural injections and costs in the Medicare population: a comparative evaluation of 1997, 2002, and 2006 data. Pain Physician. 2010;13:199-212.

182. Rosas HG, Lee KS. Performing fluoroscopically guided interlaminar lumbar epidural injections. AJR Am J Roentgenol. 2012;199:419.

183. Inman SL, Faut-Callahan M, Swanson BA, Fillingim RB. Sex differences in responses to epidural steroid injection for low back pain. J Pain. 2004;5:450-7.

184. Kirpalani D, Mitra R. Is chronic opioid use a negative predictive factor for response to cervical epidural steroid injections? J Back Musculoskelet Rehabil. 2011;24:123-7.

185. Park CH, Lee SH. Correlation between severity of lumbar spinal stenosis and lumbar epidural steroid injection. Pain Med. 2014;15:556-61.

186. Epstein NE. The risks of epidural and transforaminal steroid injections in the Spine: commentary and a comprehensive review of the literature. Surg Neurol Int. 2013;4:S74-93.

187. Horlocker TT, Wedel DJ, Benzon H, Brown DL, Enneking FK, Heit JA, et al. Regional anesthesia in the anticoagulated patient: defining the risks (the second ASRA Consensus Conference on Neuraxial Anesthesia and Anticoagulation). Reg Anesth Pain Med. 2003;28:172-97.

188. Windsor RE, Storm S, Sugar R. Prevention and management of complications resulting from common spinal injections. Pain Physician. 2003;6:473-83.

189. Furman MB, O'Brien EM, Zgleszewski TM. Incidence of intravascular penetration in transforaminal lumbosacral epidural steroid injections. Spine (Phila Pa 1976). 2000;25:2628-32.

190. Smuck M, Fuller BJ, Yoder B, Huerta J. Incidence of simultaneous epidural and vascular injection during lumbosacral transforaminal epidural injections. Spine J. 2007;7:79-82.

191. Smuck M, Tang CT, Fuller BJ. Incidence of simultaneous epidural and vascular injection during cervical transforaminal epidural injections. Spine (Phila Pa 1976). 2009;34:E751-5.

192. Sullivan WJ, Willick SE, Chira-Adisai W, Zuhosky J, Tyburski M, Dreyfuss $P$, et al. Incidence of intravascular uptake in lumbar spinal injection procedures. Spine (Phila Pa 1976). 2000;25:481-6.
193. Dawley JD, Moeller-Bertram T, Wallace MS, Patel PM. Intraarterial injection in the rat brain: evaluation of steroids used for transforaminal epidurals. Spine (Phila Pa 1976). 2009;34:1638-43.

194. Okubadejo GO, Talcott MR, Schmidt RE, Sharma A, Patel AA, Mackey RB, et al. Perils of intravascular methylprednisolone injection into the vertebral artery. An animal study. J Bone Joint Surg Am. 2008;90:1932-8.

195. Benzon HT, Chew TL, McCarthy RJ, Benzon HA, Walega DR. Comparison of the particle sizes of different steroids and the effect of dilution: a review of the relative neurotoxicities of the steroids. Anesthesiology. 2007;106:331-8.

196. Dreyfuss P, Baker R, Bogduk N. Comparative effectiveness of cervical transforaminal injections with particulate and nonparticulate corticosteroid preparations for cervical radicular pain. Pain Med. 2006;7:237-42.

197. El-Yahchouchi C, Geske JR, Carter RE, Diehn FE, Wald JT, Murthy NS, et al. The noninferiority of the nonparticulate steroid dexamethasone vs the particulate steroids betamethasone and triamcinolone in lumbar transforaminal epidural steroid injections. Pain Med. 2013;14:1650-7.

198. Kennedy DJ, Plastaras C, Casey E, Visco CJ, Rittenberg JD, Conrad B, et al. Comparative effectiveness of lumbar transforaminal epidural steroid injections with particulate versus nonparticulate corticosteroids for lumbar radicular pain due to intervertebral disc herniation: a prospective, randomized, double-blind trial. Pain Med. 2014;15:548-55.

199. Manchikanti L, Pampati V, Beyer C, Damron K, Cash K, Moss T. The effect of neuraxial steroids on weight and bone mass density: a prospective evaluation. Pain Physician. 2000;3:357-66.

200. Maillefert JF, Aho S, Huguenin MC, Chatard C, Peere T, Marquignon MF, et al. Systemic effects of epidural dexamethasone injections. Rev Rhum Engl Ed. 1995;62:429-32.

201. Younes M, Neffati F, Touzi M, Hassen-Zrour S, Fendri Y, Bejia I, et al. Systemic effects of epidural and intra-articular glucocorticoid injections in diabetic and non-diabetic patients. Joint Bone Spine. 2007;74:472-6.

202. Kay J, Findling JW, Raff H. Epidural triamcinolone suppresses the pituitary-adrenal axis in human subjects. Anesth Analg. 1994; 79:501-5.

203. Pountos I, Panteli M, Georgouli T, Giannoudis PV. Do mesenchymal stem cells have a role to play in cutaneous wound healing? Cell Tissue Transplant Ther. 2014;6:11-7.

204. Baker R, Dreyfuss P, Mercer S, Bogduk N. Cervical transforaminal injection of corticosteroids into a radicular artery: a possible mechanism for spinal cord injury. Pain. 2003;103:211-5.

205. Heavner JE, Racz GB, Jenigiri B, Lehman T, Day MR. Sharp versus blunt needle: a comparative study of penetration of internal structures and bleeding in dogs. Pain Pract. 2003;3:226-31.

206. Karasek M, Bogduk N. Temporary neurologic deficit after cervical transforaminal injection of local anesthetic. Pain Med. 2004;5:202-5.

207. Smuck M, Maxwell MD, Kennedy D, Rittenberg JD, Lansberg MG, Plastaras CT. Utility of the anesthetic test dose to avoid catastrophic injury during cervical transforaminal epidural injections. Spine J. 2010;10:857-64.

208. Smuck M, Fuller BJ, Chiodo A, Benny B, Singaracharlu B, Tong $\mathrm{H}$, et al. Accuracy of intermittent fluoroscopy to detect intravascular injection during transforaminal epidural injections. Spine (Phila Pa 1976). 2008;33:E205-10.

209. Smuck MW, Levin JH. Re: Scanlon GC, Moeller-Bertram T, Romanowsky SM, et al. Cervical transforaminal epidural steroid injections: more dangerous than we think? Spine (Phila Pa 1976). 2007;32:1249-56 (letter).

210. Manchikanti L, Candido KD, Singh V, Gharibo CG, Boswell MV, Benyamin RM, et al. Epidural steroid warning controversy still dogging FDA. Pain Physician. 2014;17:E451-74. 